\title{
Faith in the God who Resurrects: The Theocentric Faith of Hebrews
}

\author{
MATTHEW C. EASTER \\ Missouri Baptist University, One College Park Drive, St. Louis, MO 63141, USA. \\ Email: Matthew.Easter@mobap.edu
}

This article investigates the object of faith in the Epistle to the Hebrews, and argues that the object of faith is God and not Jesus. God is the object of faith in Hebrews because God is the one who holds the power of resurrection, the eschatological hope of both the faithful one par excellence (Jesus) and those who follow him. The author of Hebrews expects his persecuted community to place their faith in God in hope of being raised with Jesus, the resurrected faithful one who also placed his faith in God.

Keywords: faith, Hebrews, resurrection, death, hope, God

\section{Introduction}

The Epistle to the Hebrews provides some of the richest insights into the meaning of faith in the New Testament. Faith does not usually have an object in Hebrews, and I will show below that whenever the author of Hebrews does have an object of faith, that object is God and not Jesus. In this present study, I investigate the question of 'Why?' That is, 'For what reason should a person have faith in God, according to Hebrews?' I argue that God is the object of faith in Hebrews because God is the one who holds the power of resurrection, the eschatological hope of both the faithful one par excellence (Jesus) and those who follow him. First, I will show that Jesus is not the object of faith in Hebrews. Then, I will work through each passage where there is an object of faith and show how in each case God is that object, and that God as object of faith is connected directly with God's ability to raise the dead. ${ }^{1}$

1 Ultimately, this will further support my larger project in Hebrews, which connects faith with the hope of resurrection (M. C. Easter, Faith and the Faithfulness of Jesus in Hebrews (SNTSMS, Cambridge: Cambridge University Press, 2014)). It also builds on David Moffitt's work, which has done much to show the central importance of the resurrection for Hebrews (D. M. Moffitt, Atonement and the Logic of Resurrection (NovTSup 141; Leiden: 
A number of interpreters see Jesus as the object of human faith in Hebrews. ${ }^{2}$ Hurtado, for instance, writes: 'One of the most notable expressions of belief in Jesus in earliest Christianity is the writing known as the Epistle to the Hebrews. $^{3}$ There are three main arguments for seeing Jesus as object of faith in Hebrews, but all three prove unconvincing.

(1) Since faith and obedience are related, ${ }^{4}$ and Hebrews speaks of humans obeying Jesus (Heb 5.9), then this implies faith in Jesus. ${ }^{5}$ However, 'obedience' towards someone does not also mean faith in that person. The author of Hebrews tells his hearers to 'obey your leaders and submit to them' (Heb 13.17), but it is unlikely that he wishes his hearers to have faith in them.

(2) In Heb 13.8 the author says that Jesus is 'the same yesterday and today and forever', and in 13.7 , he urges his hearers to imitate the faith of their leaders. Hurst suggests: 'The more probable link between the two verses is that the latter is an amplification of the nature of the leaders' faith, a faith which was in Christ and his work; since he is the same "today" as he was then, they may with confidence imitate such faith. ${ }^{6}{ }^{6}$ Hurst's interpretation of Heb 13.7-8 is weakened by three observations. First, the leaders' faith which the hearers are to imitate is probably connected not with belief (as a faith in Christ), but with faithfulness, 'the outcome of their way of life' (13.7). This 'outcome' may be their deaths, and so speaks of a faith that endures to death. ${ }^{7}$ Second, the connection between the leaders' faith in 13.7 and

Brill, 2011)). Moffitt likewise sees a connection between faith in God and God's power to resurrect, but he does not develop this theme in as much detail (pp. 184, 191)).

2 See, among others, D. Hamm, 'Faith in the Epistle to the Hebrews: The Jesus Factor', CBQ 52.2 (1990) 272, 291; L. D. Hurst, The Epistle to the Hebrews: Its Background of Thought (SNTSMS 65; Cambridge: Cambridge University Press, 1990) 119-20; C. A. Thomas, A Case for MixedAudience with Reference to the Warning Passages in the Book of Hebrews (New York: Peter Lang, 2008) 259-60; B. F. Westcott, The Epistle to the Hebrews: The Greek Text with Notes and Essays (originally published 1889; Eugene, OR: Wipf and Stock, 2001) 395. For more on my engagement with those who find Jesus as object of faith, see Easter, Faith and the Faithfulness of Jesus in Hebrews, 187-94.

3 L. W. Hurtado, Lord Jesus Christ: Devotion to Jesus in Earliest Christianity (Grand Rapids: Eerdmans, 2003) 497 (emphasis added).

4 See my discussion in Easter, Faith and the Faithfulness of Jesus in Hebrews, 198-9.

5 Hamm, 'Faith', 291.

6 Hurst, The Epistle to the Hebrews, 120. See also D. deSilva, Perseverance in Gratitude: A SocioRhetorical Commentary on the Epistle 'to the Hebrews' (Grand Rapids: Eerdmans, 2000) 494; C. R. Koester, Hebrews (AB 36; New York: Doubleday, 2001) 567; and W. L. Lane, Hebrews 9-13 (WBC 47B; Dallas: Word, 1991) 528.

7 On the outcome $(\check{\varepsilon} \kappa \beta \alpha \sigma 1 \varsigma)$ as their death, see H. W. Attridge, The Epistle to the Hebrews (Hermeneia; Philadelphia: Fortress, 1989) 392; deSilva, Perseverance in Gratitude, 494; 
Jesus in 13.8 is not necessarily located in Jesus as the object of faith, but could recall Jesus as the basis of faith. That is, given that Jesus is consistent as the one who 'is the same yesterday and today and forever', we have reason for faith. ${ }^{8}$ Third, Hurst misses other connections in the immediate context showing that the issue at hand is not faith in Christ, but the consistency of Jesus. Heb 13.8 may look ahead to the exhortation not to be led away by divergent teachings (13.9). That is, rather than follow diverse and strange teachings, we should remember that Jesus Christ is consistent as one who is 'the same yesterday and today and forever' ${ }^{9}$ Furthermore, the leaders' faith in 13.7 could point back to 13.6, where the author reminds us that 'we can confidently say, "The Lord is my helper; I will not fear; what can a person do to me?"' Their faith to the end demonstrates the truth of this scripture quotation. Therefore, Hurst's reading of $13.7-8$ ultimately fails to convince.

(3) Others have suggested that Hebrews implies faith in Jesus when describing faith in God. ${ }^{10}$ Rhee, for example, notes that the author of Hebrews thinks of Jesus as God (as in Heb 1.8), and for this reason should be considered the object of faith. ${ }^{11}$ Later, Rhee equates 'faith toward God' in 6.1 with 'faith in Christ'. ${ }^{12}$ Nevertheless, even if we grant Rhee that Jesus being God makes him the object of faith, this does not demonstrate Christ as object of faith, but God as object. Jesus would be object of faith only by virtue of his being God.

Instead of Jesus being the object of faith, the author of Hebrews explicitly or implicitly speaks of God as object of faith (2.13; 3.12, 19; 4.2, 3; 5.7-9; 6.1; 11.6, 11, 19). In each case, as we will see, the faith directed towards God is associated with the hope of resurrection. I will not be addressing every place where there might be the hope of resurrection. Indeed, Hebrews addresses resurrection

P. Ellingworth, The Epistle to the Hebrews (NIGTC; Grand Rapids: Eerdmans, 1993) 703; and Koester, Hebrews, 567.

8 See also E. Grässer, Der Glaube im Hebräerbrief (Marburger Theologische Studien 2; Marburg: N. G. Elwert, 1965) 29-30.

9 On this connection, see also Ellingworth, Hebrews, 706; Hamm, 'Faith', 275; Lane, Hebrews 9-13, 528-9.

10 For instance, Hamm, 'Faith', 291.

11 V. (S.-Y.) Rhee, Faith in Hebrews: Analysis within the Context of Christology, Eschatology, and Ethics (Studies in Biblical Literature 19; New York: Peter Lang, 2001) 56.

12 Rhee, Faith in Hebrews, 125. This, however, contradicts his earlier claim, where he writes: 'In 6:1 the author of Hebrews clearly makes a distinction between Christ and God. For this reason

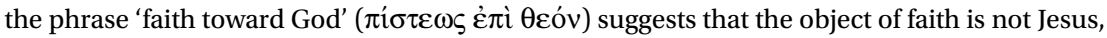
but God the Father' (p. 58). 
without clearly implying faith in God $(11.35 ; 13.19-20)$. I restrict myself to cases where faith in God is present in Hebrews. In each case we will discover that faith in God is motivated by confidence that God holds the power of resurrection. ${ }^{13}$

\section{Faith through Suffering (Heb 2.13)}

In Heb 2.13, Jesus speaks the words of Isa 8.17: 'I will put my trust in him

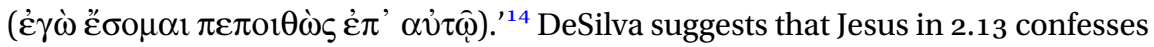
trust not in God, but in human beings, his brothers and sisters. ${ }^{15}$ However, in 2.13 Jesus confesses trust in a singular $\alpha \hat{\tau} \tau \hat{\omega}$. Throughout the context in Heb 2.10-18, the author of Hebrews speaks of human beings in the plural ( $\pi \mathrm{o} \lambda \lambda \mathrm{\alpha}$ ì $\varsigma$ vioú $\varsigma$ in 2.10; oi $\alpha \gamma 1 \alpha \zeta o ́ \mu \varepsilon v o 1$ and $\dot{\alpha} \delta \varepsilon \lambda \varphi o v ́ \varsigma$ in 2.11; $\alpha \delta \varepsilon \lambda \varphi o i s ~ i n ~ 2.12 ; \pi \alpha 1 \delta i ́ \alpha$ in 2.14;

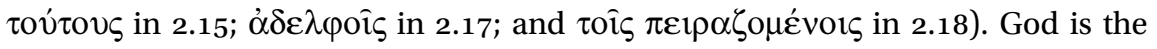
only singular figure in the context ( $\alpha \dot{\tau} \tau \hat{\omega}$ in 2.10; ö ... $\alpha \gamma i \alpha \hat{\alpha} \zeta \omega \mathrm{V}$ in 2.11; and $\sigma \varepsilon$

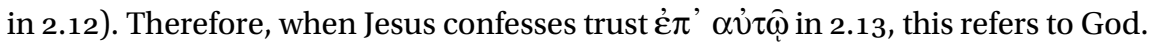

Jesus trusts God, I suggest, because he believes that God can raise him from the dead. Jesus' confession of trust in Heb 2.13 is one of trust through suffering. Jesus, who for a short time was made lower than the angels, received the crown of glory and honour on account of his suffering of death (2.9). God made Jesus perfect through sufferings (2.10). Jesus became like his human siblings in every way so that 'through death he might destroy the one who has the power of death' (2.14), and free humanity from slavery to the fear of death (2.15). Jesus made atonement for the sins of the people (2.17), which clearly implies his death $(9.12-15 ; 10.10,19 ; 13.12)$. Jesus' trust in 2.13 , therefore, is a trust in God in the midst of suffering.

It is within this context of death that the author puts the words of Ps 21.23 LXX on the lips of Jesus: 'I will announce your name among my brothers and sisters; in the midst of the congregation I will praise you' (Heb 2.12). Psalm 21 LXX is a plea for help in suffering, in anticipation of deliverance. ${ }^{16}$ The psalmist experiences abandonment (21.2-3) and ill treatment from others (21.7-19). In motifs repeated in the passion traditions in the Gospels, he feels forsaken (Ps 21.2; Matt 27.46; Mark 15.34) as he is poured out like water (Ps 21.15; John 19.34), experiences

13 This essay, then, is driven by the question of why people have faith in God in Hebrews, and not the question of how resurrection plays an instrumental role in Hebrews. Here again on this question I defer to Moffitt, Atonement. For the resurrection of Jesus and humanity's hope of resurrection, see Easter, Faith and the Faithfulness of Jesus in Hebrews, 107-31.

14 This phrase appears in 2 Sam 22.3; Isa 8.17; 12.2. Given that the latter half of Heb 2.13 ('behold, I and the children God has given me') is from Isa 8.18, the author is most likely quoting Isa 8.17

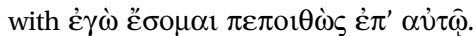

15 DeSilva, Perseverance in Gratitude, 116.

16 J. Goldingay, Psalms, vol. I: Psalms 1-41 (Baker Commentary on the Old Testament Wisdom and Psalms; Grand Rapids: Eerdmans, 2006) 340. 
extreme thirst (Ps 21.16; John 19.28), and others cast lots for his clothing (Ps 21.19; Matt 27.35; Mark 15.24; Luke 23.34; John 19.24). In Ps 21.21-2 (the verses immediately prior to the verse quoted in Hebrews), he begs for deliverance from death: 'Deliver my soul from the sword, and my only life from the dog's hand. Save me from the lion's mouth, and my humiliation from the unicorns' horns.' The psalmist moves from lament to jubilant confidence, with the promise to 'tell of your name to my kindred' (21.23) and the exhortation to praise the Lord because he has heard the petition of the poor (21.24-7). As Lane notes, this latter half of the psalm 'is appropriate to an experience of vindication and exaltation after suffering and affliction'. ${ }^{17}$ Having endured suffering (as noted in the contexts of both Hebrews 2 and Psalm 21, quoted in Heb 2.12), Jesus now rejoices in vindication. ${ }^{18}$ Peter C. Craigie's messianic reading of the ending of Psalm 21 would apply here:

The psalm concludes with praise because the sufferer escaped death; Jesus died. Yet the latter half of the psalm (vv 22-32) may also be read from a messianic perspective. The transition at $\mathrm{v} 22$ is now understood not in deliverance from death, as was the case for the psalmist, but in deliverance through death, achieved in the resurrection. And it is that deliverance which is the ground for praise. $^{19}$

Jesus' confession of trust in Heb 2.13, therefore, is a faith in the face of suffering that realises reward following the suffering. God, the object of this trust ( $\pi \varepsilon \pi \mathrm{or} \theta \omega \varsigma \mathrm{\varsigma}$ 'ं $\pi^{\prime} \alpha \cup(\hat{)})$, is the one with this resurrecting power. By placing his faith in God in the midst of his suffering of death, Jesus demonstrates a trust in the only one who can deliver him, even if he dies.

\section{Faith to Enter God's Rest (Hebrews 3.12, 19; 4.2-3)}

God is clearly the object of faith in Hebrews 3-4. He is the one whose voice we are to hear $(3.7,15)$ and into whose rest we are to enter $(4.1 ; 9-11)$. The need to trust God is evident in light of the Kadesh narrative undergirding these verses (see Ps 95.7-11 quoted in Heb 3.7-11, which refers to Num 14), where the wilderness generation had to trust God to bring them into the Promised Land and so move forward into 'the rest'. Against this backdrop, when the author warns against an 'evil, unbelieving heart' (3.12), this is likely a heart that does not trust God (cf. Num 14.11). Similarly, the wilderness generation failed to enter the rest 'because of unbelief ( $\left.\delta \mathrm{\imath}^{\prime} \dot{\alpha} \pi \mathrm{\imath \tau} \tau^{\prime} \alpha v\right)$ ' (3.19). They were not 'united in faith

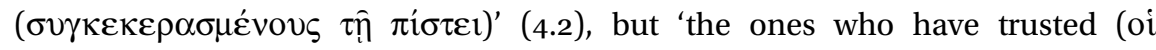

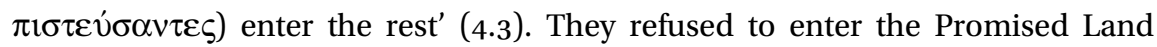

17 W. L. Lane, Hebrews 1-8 (WBC 47A; Nashville, TN: Thomas Nelson, 1991) 59.

18 See also G. H. Guthrie, 'Hebrews', Commentary on the New Testament Use of the Old

Testament (ed. G. K. Beale and D. A. Carson; Grand Rapids: Baker Academic, 2007) 949.

19 P. C. Craigie, Psalms 1-5o (WBC 19; Waco, TX: Word Books, 1983) 203 (emphasis original). 
because they did not trust God to bring them safely into the land (cf. Num 14.8). In Hebrews 3-4, therefore, God is the object of faith.

Hebrews 3-4 does not directly connect trust in God with God's power to resurrect. However, I suggest that resurrection is prerequisite to entering the rest. If I am correct that this rest can be inhabited only by resurrected humans, and trust in God is a requirement for entering it (4.2-3), then it possible that God's resurrecting power is the basis on which the author of Hebrews urges his hearers to trust God.

The rest is one of many images in Hebrews referring to the eschatological hope. Along with salvation $(1.14 ; 2.10 ; 5.7,9 ; 6.9 ; 7.25 ; 9.28)$, promise (4.1; 9.15; $10.36 ; 11.13,39)$, reward $(10.35 ; 11.6,26)$, promised eternal inheritance (9.15) and an enduring homeland to come $(2.5 ; 10.34 ; 11.10,14,16 ; 12.22,28 ; 13.14)$, it depicts an eschatological hope in the heavenly realm that is reserved for resurrected human beings.

That the rest is in the heavenly realm is indicated by two observations. First, the author exhorts his hearers to enter rest $(3.11,18,19 ; 4.1,3,5,6,10,11)$. The metaphor of movement elsewhere in Hebrews is often associated with the divine realm. ${ }^{20}$ Second, the rest is consistently described as God's rest. When

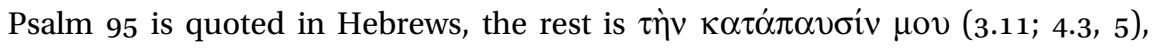

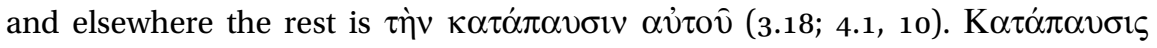

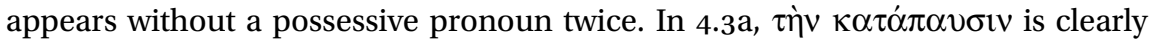

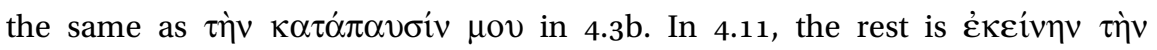

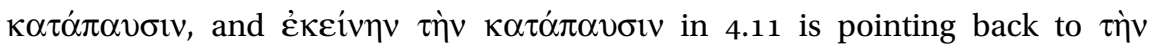

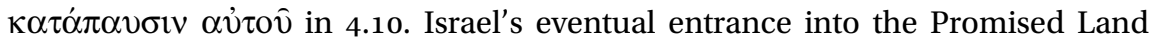
under Joshua was not a full realisation of the rest (4.8) precisely because the land was on earth, and not God's rest in the heavenly presence of God. ${ }^{21}$ The rest, then, is the heavenly presence of God.

This rest in the heavenly realm can be inhabited only by human beings who have received an enduring life by resurrection. God did not subject the coming

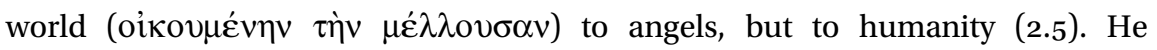
intends for humanity to be crowned with glory and honour (2.7), with all things in subjection to them (2.8). Even though angels appear in the heavenly Jerusalem (12.22), the author makes clear elsewhere that they exercise no dominion $(1.13 ; 2.5)$ but worship the Son $(1.6)$ and serve the Son and humanity $(1.7,14)$.

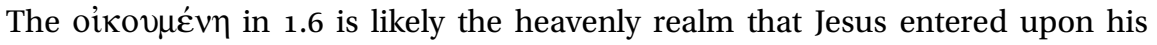
exaltation. Moffitt has argued convincingly that Jesus must be an embodied

20 D. deSilva, 'Entering God's Rest: Eschatology and the Socio-Rhetorical Strategy of Hebrews', TJ 21 (2000) 25-43, at 38-9; K. Son, Zion Symbolism in Hebrews: Hebrews 12:18-24 as a Hermeneutical Key to the Epistle (Paternoster Biblical Monographs; Milton Keynes: Paternoster, 2005) 138-9.

21 K. Backhaus, 'Das Land der Verheißung: Die Heimat der Glaubenden im Hebräerbrief', NTS 47 (2001) 171-88, esp. at 178. 
human being in order to enter this heavenly realm. ${ }^{22}$ As Moffitt shows, this is made evident in Heb 1.7-9, which contrasts the angels' spiritual nature with Jesus' exaltation to the right hand of God. The angels are $\pi v \varepsilon v ́ \mu \alpha \tau \alpha$, God's ministers who are flames of fire (1.7), but the Son possesses God's throne and exercises dominion (1.8). Curiously, the author of Hebrews sees the angels' spiritual

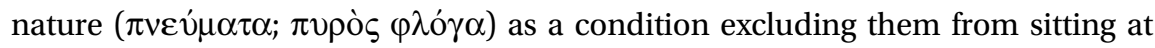
the right hand of God. He does not root Jesus' right to exercise royal dominion in his eternal nature (as described in 1.2-3). Instead, he says that Jesus was anointed beyond his companions (1.9), which suggests that he was one of number in his human peer-group who could have received such dominion. ${ }^{23}$ God intended glory, honour and dominion for human beings (2.5-9), and from among these companions Jesus was invited to sit at God's right hand. Jesus' embodied humanity, therefore, qualifies him to enter the heavenly realm. ${ }^{24}$ Since embodied humanity is the necessary qualification to enter the heavenly realm (God's rest), and since embodied humans die, resurrection is a necessary condition for enjoyment of the eschatological hope.

As the author makes clear in Heb 4.3, a person can enter God's rest only by faith in God. God is the one with the power to bring people into God's rest, and therefore the one with the power of resurrection. Therefore, when the author of Hebrews encourages his hearers to trust God in order to enter the rest, he is encouraging them to trust in the one who holds the power of resurrection.

\section{Faith in the One Able to Save Out of Death (Heb 5.7-9)}

In Heb 5.7-9, Jesus is offering prayers and supplications with loud cries and

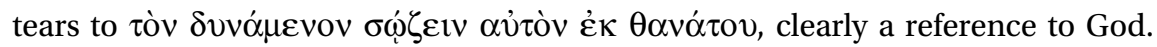
Although the author does not use a $\pi 1 \sigma \tau$ - word to describe Jesus in 5.7-9, he depicts him exercising faith in God even in the face of death. Patrick Gray has argued at length for reading $\varepsilon \dot{\nu} \lambda \alpha \dot{\beta} \varepsilon 1 \alpha$ as 'godly fear' (5.7). ${ }^{25}$ Cries or tears in

22 Moffitt, Atonement, 50-2.

23 That Jesus' peers were not angels is clear in 1.5 and 1.13, where the author introduces the psalm quotations with 'To which of the angels has he ever said?'

24 Moffitt, Atonement, 143. See also Heb 9.12, where Jesus enters the heavenly holy places

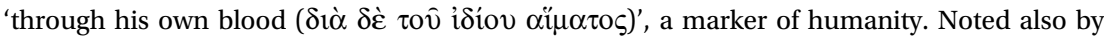
S. Motyer, "Not Apart from Us" (Hebrews 11:40): Physical Community in the Letter to the Hebrews', EQ 77.3 (2005) 235-47, at 239.

25 P. Gray, Godly Fear: The Epistle to the Hebrews and Greco-Roman Critiques of Superstition (SBL Academia Biblica 16; Atlanta: SBL, 2003) 188-205. See also C. Maurer, "'Erhört wegen der Gottesfurcht”, Hebr 5,7', Neues Testament und Geschichte: Historisches Geschehen und Deutung im Neuen Testament. Oscar Cullmann zum 7o. Geburtstag (ed. B. Reicke and H. Baltensweiler; Tübingen: Mohr Siebeck, 1972) 275-84. 
the LXX are often used of prayers for deliverance in times of crisis (as in Exod 3.7, 9; 2 Sam 22.7; 2 Kings 20.5; Neh 9.9; Ps 18.6; Isa 30.19; 38.5; Jonah 2.2; 2 Macc 11.6; 3 Macc $1.16 ; 5.7,25) .{ }^{26}$ The author of Hebrews depicts Jesus in the vein of a righteous sufferer who in a time of distress directs fervent prayers to the God who can deliver.

More particularly, the author may intend to place Jesus in the context of Psalm $21 \mathrm{LXX}^{27}$ That he has Psalm 21 in mind is substantiated by three observations. First, the author of Hebrews refers to the passage elsewhere, which shows that he is familiar with the psalm. As already noted, the author quotes part of Psalm 21 in Hebrews 2. In addition, Heb 4.16, in which the author encourages his hearers to approach the throne of grace so that they might receive help ( $\beta o \eta \dot{\theta} \varepsilon 1 \alpha v$ ), may parallel Ps 21.12, where the psalmist asks God to stay near to him because there is no one to help ( $\beta$ no $\theta \hat{\omega} v)$. Later, the psalmist repeats his request and this time speaks of God as his help ( $\beta$ on $\theta \varepsilon ı \alpha, 21.20) .{ }^{28}$ Second, Heb 5.8 notes that Jesus learned obedience, 'although he was a son'. The author also adopts familial language from Psalm 21 in Heb 2.12 ('I will tell of your name to my brothers and sisters'), and the mention of Jesus' sonship in Heb 5.8 may echo this earlier quotation from Psalm 21. Third, Heb 5.7-9 and Psalm 21 feature a number of similar words. In Ps 21.25, the psalmist rejoices that God 'did not despise nor abhor the prayer ( $\tau \hat{n} \delta \varepsilon \eta \dot{\sigma \varepsilon l) ~ o f ~ t h e ~ p o o r, ~ n o r ~ d i d ~}$

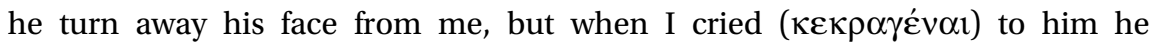

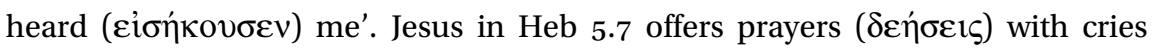

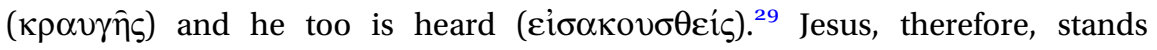
firmly in the tradition of a faithful righteous sufferer who turns to God in faith in hope of deliverance.

26 See also Philo, Leg. 3.213; Her. 19; and esp. Det. 92-93. Attridge, Hebrews, 151 nn. 172 and 173; Koester, Hebrews, 288.

27 Hebrews shows little engagement with other traditions of the righteous sufferer in the LXX,

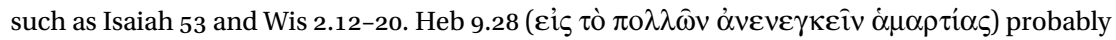

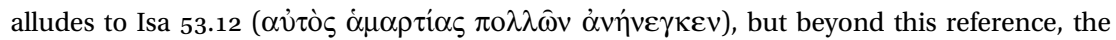
author of Hebrews does not explicitly depict Jesus as the Isaian servant (see O. Hofius, 'The Fourth Servant Song in the New Testament Letters', The Suffering Servant: Isaiah 53 in Jewish and Christian Sources (ed. B. Janowski and P. Stuhlmacher; Grand Rapids: Eerdmans, 2004) $163-88$, at 184-5). While we need not eliminate the possibility that the author of Hebrews is informed by Isaiah 53 and/or Wis 2.12-20, Psalm 21 is more clearly in view for the reasons I adduce.

28 C. Richardson, 'The Passion: Reconsidering Hebrews 5.7-8', A Cloud of Witnesses: The Theology of Hebrews in its Ancient Contexts (ed. R. Bauckham et al.; Library of New Testament Studies 387; London: T\&T Clark, 2008) 51-67, at 66 n. 58.

29 F. F. Bruce, The Epistle to the Hebrews (NICNT; Grand Rapids: Eerdmans, 1990, revised edn) 128. 
The author does not make it clear as to what Jesus was praying for, but I suggest that Jesus is trusting God to raise him from the dead. Four observations show that Jesus prayed for deliverance out of death, and was heard by being raised.

(1) The author describes God as 'the one able to save him out of death ( $\dot{\varepsilon} \kappa$

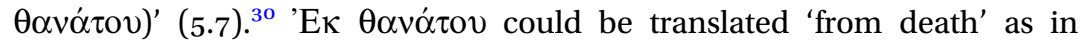
being saved from the experience of death, but this reading falters for three reasons. First, Jesus praying for deliverance from the experience of death makes little sense given that the author and hearers of Hebrews knew that he had in fact died. If Jesus were praying for salvation from the experience of death, then he was in fact not heard. Second, as Ellingworth rightly notes, ' $[\mathrm{t}$ ] he author of Hebrews insists so strongly on the positive results of Christ's suffering and death $(2: 9,14 ; 9: 15)$ that it is antecedently improbable that he would speak here of Christ's attempting to avoid them'.$^{31}$ The author of Hebrews depicts Jesus in $\mathbf{1 2 . 2}$ as intentionally enduring the cross 'for the joy that was set before him'. Jesus knew of the rewards following death, and it is therefore unlikely that he is praying for deliverance from the experience of death in 5.7. Finally, the author of Hebrews consistently upholds Jesus' suffering as a salvific act that he undertakes voluntarily $(2.13 ; 9.26 ; 10.7,9$; 12.2), and so it is unlikely that he would depict Jesus as praying to avoid such suffering. ${ }^{32}$ Jesus, therefore, prayed for deliverance despite his death. God heard Jesus' prayers, and answered him in resurrection. If in calling

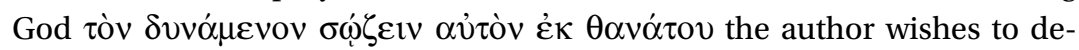
scribe God as someone able to do what Jesus needed at the present time, then Jesus' prayer as a prayer for deliverance via resurrection is more clearly in view.

(2) The author of Hebrews emphasises Jesus' endurance of suffering (5.8) and his subsequent perfection (5.9). Jesus' suffering is elsewhere associated with eschatological reward (glory and honour in 2.9; perfection in 2.10; session at the right hand of God in 12.2). So also Jesus' suffering in 5.7-9 is probably a precursor to his enjoyment of life beyond death.

(3) The author says that Jesus was made perfect ( $\tau \varepsilon \lambda \varepsilon i \omega \theta \varepsilon i \varsigma)$ after learning obedience through suffering (5.8-9). While 'perfection' is not a technical term for resurrection in every instance in Hebrews (as in 5.14 ; 6.1; 9.9;

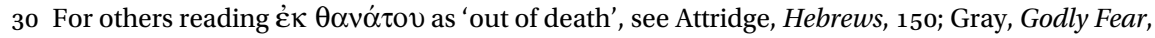
192; J. Kurianal, Jesus our High Priest: Ps 110,4 as the Substructure of Heb 5,1-7,28 (European University Studies 693; Frankfurt am Main: Peter Lang, 2000) 70; D. M. Moffitt, "If Another Priest Arises": Jesus' Resurrection and the High Priestly Christology of Hebrews', A Cloud of Witnesses, 68-79, at 69-70; Richardson, 'Passion', 60; and Westcott, Hebrews, 124, 126. For

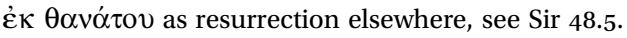

31 Ellingworth, Hebrews, 288.

32 Richardson, 'Passion', 61. 
$10.1,14)$, resurrection is in view each time Jesus is said to have been perfect (2.10; 5.9; 7.28). In Heb 2.9, the author introduces Jesus as one who was crowned with glory and honour because of the suffering of death ( $\delta i \grave{\alpha}$ iò

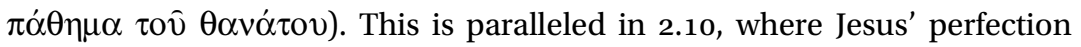

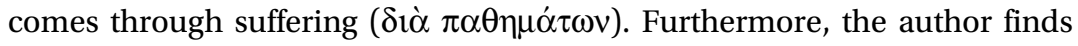
it fitting that God would bring many sons and daughters to glory by making the pioneer of their salvation perfect through sufferings. In the next verse, Jesus is named a brother with these sons and daughters, which suggests that he too was being brought to glory. The glory is equivalent to the perfection which Jesus experienced through suffering. ${ }^{33}$ Therefore, perfection, glory and honour probably point to the same general idea. Further, this perfection (as well as glory and honour) comes through suffering. That this suffering is a suffering in death is clear in context. ${ }^{34}$ Although it is not immediately clear that Jesus' perfection comes after suffering rather than along with suffering, it is likely that his perfection follows his death. As noted above, Jesus in 2.9 is crowned with glory and honour because of

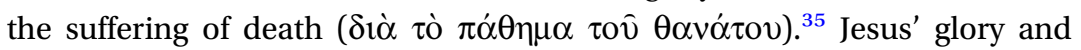
honour are the result of his suffering of death. Given the close similarity between glory, honour and perfection in Heb 2.9-10, we see that Jesus was made perfect after his death. ${ }^{36}$ Outside $5.7-9$, the other reference to Jesus' perfection appears in Heb 7.28, where the author argues that Jesus' high priesthood is contingent upon his enduring life after death. ${ }^{37}$

Two further points indicate that Jesus' perfection is closely associated with resurrection in Heb 5.7-9. First, his perfection is contrasted with 'the days of his flesh', during which he learned through suffering. ${ }^{38}$ 'The days of his flesh' clearly refers to Jesus' days on earth, and so his perfection must relate to a time following his earthly life. Second, Jesus' perfection through suffering in $\mathbf{5 . 9}$ deals with eternal salvation: 'having been made perfect, (Jesus) became the source of eternal salvation to all who obey

33 On the association between perfection and glory, see also Kurianal, Jesus our High Priest, 228-9; J. M. Scholer, Proleptic Priests: Priesthood in the Epistle to the Hebrews (JSNTSup 49; Sheffield: Sheffield Academic, 1991) 195-6. For parallels between suffering, exaltation and perfection in Hebrews, see the chart in M. Silva, 'Perfection and Eschatology in Hebrews', WTJ 39.1 (1976) 60-71, at 66.

34 In 2:9, the suffering is a suffering of death ( for everyone. In 2:14, Jesus destroys the one with the power of death through his death.

35 On $\delta 1 \alpha$ with the accusative as causal, see Daniel B. Wallace, Greek Grammar: Beyond the Basics (Grand Rapids: Zondervan, 1996) 369.

36 See also deSilva, Perseverance in Gratitude, 197; Joshua W. Jipp, 'The Son's Entrance into the Heavenly World: The Soteriological Necessity of the Scriptural Catena in Hebrews 1.5-14,' NTS 56 (2010) 557-75, at 570-1; Kurianal, Jesus Our High Priest, 300-301 and 300 n 42.

37 See Moffitt, Atonement, 200-8.

38 DeSilva, Perseverance in Gratitude, 198. 
him'. If perfection is something that humanity hopes to share in (as 11.40 suggests), then this perfection is associated with the eternal salvation that Jesus secures. Jesus as the source of eternal salvation in 5.9 recalls Jesus as the $\dot{\alpha} \rho \chi \eta \gamma$ ó $\varsigma$ of salvation in 2.10, where he is the one through whom God is bringing many children to glory. Perfection, then, is closely associated with the eternal salvation that Jesus secures, as God is bringing many children to glory. ${ }^{39}$

(4) That Jesus is trusting God in hope of resurrection is intimated by references to Jesus being a priest forever after the order of Melchizedek in the context $(5.6,10)$. Hebrews 7 discusses the enigmatic figure of Melchizedek and attributes Jesus' priesthood qualifications to his being after the order of Melchizedek. Jesus is descended from Judah (not Levi), and so is disqualified from being a priest on earth (7.14). Jesus' priesthood is not ratified on the basis of his genealogical lineage, but on the basis of his 'indestructible

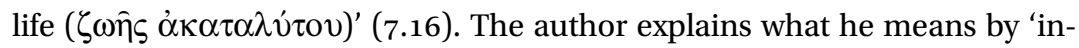
destructible life' with a quotation from Ps 110.4: 'You are a priest forever, after the order of Melchizedek' (7.17). Melchizedek, who appears years before Levi or Aaron, is a priest of the Most High God (7.1) on the basis of his unending life (7.3). Unlike the earthly priests, whose ministries are cut short by their deaths, Jesus' priesthood continues because he lives forever. However, the author of Hebrews is clear elsewhere that Jesus did in fact die, and so an implicit step for Jesus' enduring life is his resurrection. ${ }^{40}$ If Jesus' eternal priesthood after the order of Melchizedek is possible only if he is raised, then Heb 5.7-9 fits perfectly within the cultic context of 4.145.10. Christ's appointment to the high priesthood is only possible by means of his resurrected life, so the author introduces Jesus' resurrection into this discussion of Jesus' priesthood.

Therefore, in Heb 5.7-9 we see Jesus trusting God through suffering, in hope of resurrection. This 'one able to save him out of death' heard Jesus' prayers, and answered him in resurrection. Once again God is object of faith, and this faith in God is motivated by Jesus' confidence in God as the one able to raise him from the dead.

\section{Foundational Faith in God (Heb 6.1)}

In Heb 6.1, the author intends to press on to maturity while not laying

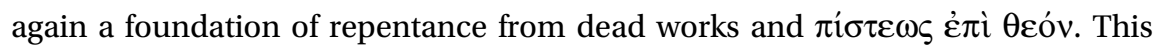

39 W. R. G. Loader, Sohn und Hoherpriester: Eine traditionsgeschichtliche Untersuchung zur Christologie des Hebräerbriefes (WMANT 53; Neukirchen-Vluyn: Neukirchener, 1981) 43. 40 So also Kurianal, Jesus our High Priest, 232; O. Michel, Der Brief an die Hebräer (KEK 13; Göttingen: Vandenhoeck \& Ruprecht, 1936) 62; Moffitt, 'If Another Priest Arises', 75-6. 
is the only place in Hebrews where the noun $\pi i \sigma \tau \imath \varsigma$ has an explicit object ( $\theta \varepsilon o ́ v)$.

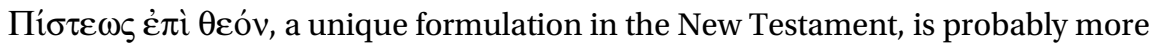
than belief in God's existence (given the absence of the abstract है $\sigma \tau \imath v$ as in 11.6). Instead, it is 'trust in and fidelity to God' ${ }^{41}$

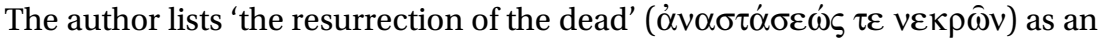
elementary doctrine (6.2). The doctrines in 6.1-2 are grouped into three pairs: (1) repentance from dead works and faith towards God; (2) washings and the laying on of hands; and (3) resurrection of the dead and eternal judgement. ${ }^{42}$

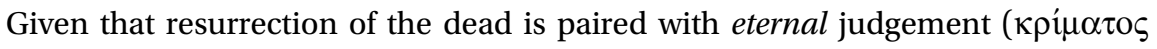
$\alpha i \omega v i o v)$, it is likely that both refer to an eschatological experience. ${ }^{43}$ As such, this resurrection is more than a resuscitation of a life that will once again end in death; it is rather a rising to an eternal life that cannot be ended. While it is not as clear here that the hope of resurrection is the motivation for faith in God, it is apparent that faith in God is associated with the hope of resurrection.

\section{Faith in the God who Rewards (Heb 11.6)}

At first glance, the faith expressed in Heb 11.6 is not as much faith in God as object as it is faith in attributes of God. The faith in view in 11.6 is (1) belief in God's existence, ${ }^{44}$ and (2) trust in God's faithfulness to reward those who seek him:

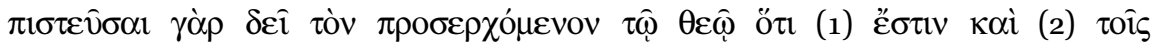

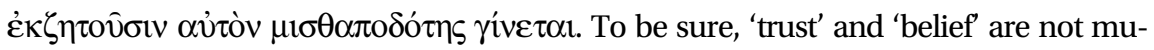
tually exclusive. 'Trusting' entails a 'belief' in the existence of the object of trust. Outside Heb 11.6, the first aspect of faith ('belief in (the existence of God/something)') is not a significant concept in Hebrews. On the other hand, as we have seen, faith in God as a rewarder (as in aspect 2 above) is a significant concept. Although God as object of faith is not as clear in $\mathbf{1 1 . 6}$ as elsewhere, the fact that faith is placed in God as the 'rewarder of those who seek him' makes it appropriate to discuss this passage here.

This second aspect of faith in 11.6 (trusting God rewards those who seek him) connects faith in God with the hope of resurrection. As noted earlier, 'reward' elsewhere in Hebrews refers to the eschatological hope. In this way, the description of God as one who rewards those who seek him harks back to Heb 5.7, where Jesus shows faith in 'the one able to save him out of death'. By describing God as the 'rewarder', the author wishes his hearers to think of the hope of resurrection.

That Heb 11.6 refers to the hope of resurrection is further strengthened by taking into account the context of the rest of the chapter. Throughout Hebrews

41 Attridge, Hebrews, 164.

42 Attridge, Hebrews, 163.

43 See also Attridge, Hebrews, 163; Moffitt, Atonement, 184.

44 On $\pi \iota \sigma \tau \varepsilon \hat{\sigma} \sigma \alpha \iota$... ö $\tau$ है $\sigma \tau \imath v$ as 'believe that God exists', see Attridge, Hebrews, 318; Koester, Hebrews, 476; Lane, Hebrews 9-13, 338. 
11 the author presents heroes from Israel's story who exemplified faith in the context of death while looking forward to enduring life in a heavenly homeland. ${ }^{45}$ Furthermore, the whole of Hebrews 11 is framed by associations of faith with life. In 10.39, the author reflects back on the quotation from Hab 2.3-4 and suggests confidently: 'we are not of timidity unto destruction, but of faith unto the preservation of the soul'. ${ }^{46}$ Likewise, in $\mathbf{1 2 . 2}$ he recalls the story of Jesus, the pioneer and perfecter of faith, whose endurance of the cross ended in glorification at the right hand of God. ${ }^{47}$ The heroes' stories in Hebrews 11 demonstrate a triumph of life despite death. Some exhibit faith by accepting death (11.36-7), others by faith avoid death in the face of dangerous threats $(11.7,17-19,23,28,29,31,33-5)$, and still others in faith look beyond their own deaths to offer hope to the living $(11.20,21,22)$. The heroes of Hebrews 11 who exemplify faith in the context of death look to the eschatological hope beyond death. The sojourning patriarchs looked forward to a God-built heavenly homeland with foundations (11.10, 1416) and those enduring torture hoped for a 'better resurrection' (11.35). ${ }^{48}$ Within this context, the description of God as 'the one who rewards

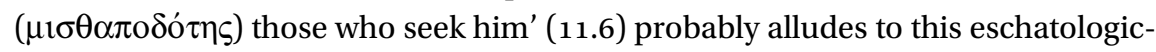
al hope as well.

Heb 11.6, therefore, is another association of faith in God and the hope of resurrection. Those wishing to draw near to God need to believe that God exists, and trust that God will reward with resurrection those who seek him.

45 This is widely recognised. See, among others, A. D. Bulley, 'Death and Rhetoric in the Hebrews "Hymn to Faith"', SR 25.4 (1996) 413-17; G. L. Cockerill, 'The Better Resurrection (Heb. 11:35): A Key to the Structure and Rhetorical Purpose of Hebrews 11', TynBul 51.2 (2000) 215-34; P. M. Eisenbaum, The Jewish Heroes of Christian History: Hebrews 11 in Literary Context (SBLDS 156; Atlanta: Scholars, 1997) 178-9; W. L. Lane, 'Living a Life of Faith in the Face of Death: The Witness of Hebrews', Life in the Face of Death: The Resurrection Message of the New Testament (ed. R. N. Longenecker; Grand Rapids: Eerdmans, 1998) 257; Moffitt, Atonement, 185; J. Swetnam, Jesus and Isaac: A Study in the Epistle to the Hebrews in Light of the Akedah (Rome: Biblical Institute, 1981) 86-9.

46 On the connection between Heb 10.37-9 and Hebrews 11, see R. Gheorghita, The Role of the Septuagint in Hebrews: An Investigation of its Influence with Special Consideration to the Use of Hab 2:3-4 in Heb 10:37-38 (WUNT II/160; Tübingen: Mohr Siebeck, 2003) 181; K. Haacker, 'Der Glaube im Hebräerbrief und die hermeneutische Bedeutung des Holocaust', TZ 39 (1983) 152-65, at 155. For my treatment of Hebrews 10.37-9, see Easter, Faith and the Faithfulness of Jesus in Hebrews, 165-78.

47 For my treatment of Hebrews 12.1-2, see Easter, Faith and the Faithfulness of Jesus in Hebrews, 133-54.

48 This could be another example of faith in God coordinating with the hope of resurrection, but since no object of faith is explicitly or implicitly named here, I am not addressing it in the current study. 


\section{Abraham's Faith in God (Heb 11.11-12, 17-19)}

Since Heb 11.11-12 and 11.17-19 both involve Abraham and share other similar themes, I address these passages together. In Heb 11.11-12, Abraham, along with Sarah, ${ }^{49}$ received the power to procreate, and considered God who promised faithful. While the author does not use a $\pi \iota \sigma \tau$ - word, Abraham's 'considering the one who promised faithful' (11.11) is rightly understood as Abraham's faith in God. Similarly, that Abraham 'considered that God was able even to raise the dead' (11.19) also refers to Abraham's faith in God.

In both 11.11-12 and 11.17-19, Abraham's faith in God is based on his hope in God's ability to resurrect. In the first case, Abraham hopes for a figurative resurrection, a resurrection of his 'dead' body ( $\alpha \varphi$ ' $\dot{\varepsilon} v o ̀ \zeta . . . v \varepsilon v \varepsilon \kappa \rho \omega \mu \varepsilon$ 'vov), so that he might father children with Sarah. ${ }^{50}$ In 11.17-19, the author credits Abraham's offering of Isaac to Abraham's consideration that 'God was even able to raise someone from the dead' (11.19). This probably refers not to Abraham's hope of an eschatological resurrection, but to an immediate resuscitation to life. The implication here seems to be that Abraham expected that if he did have to kill his promised son, then God could bring him back to life again, as God did do 'in parable ('่v $\pi \alpha \rho \alpha \beta 0 \lambda \hat{n})$ ' (11.19). ${ }^{11}$ Even so, Abraham shows a faith in God motivated by his trust in God's ability to raise the dead.

Abraham's faith in 11.17-19 reflects Jesus' faith in 5.7-9. In both cases, we see the pattern of faith in God connected with the hope of resurrection. ${ }^{52}$ Most significantly, God's power to save people out of death 'appears to be the primary

49 The translation of Heb 11.11 is notoriously difficult, as either Sarah or Abraham can be the

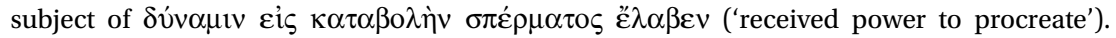

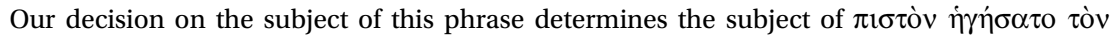
$\dot{\varepsilon} \pi \alpha \gamma \gamma \varepsilon 1 \lambda \alpha$ á $\mu \varepsilon v o v$ ('considered the one who promised faithful'). Here I adopt the Abraham reading, following Attridge, Hebrews, 325-6; deSilva, Perseverance in Gratitude, 398-9; Koester, Hebrews, 487-8; and Lane, Hebrews 9-13, 344-5. Two reasons for understanding

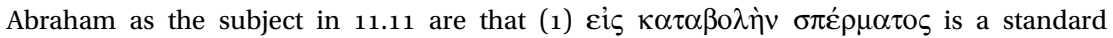
Hellenistic idiom for the male's procreative function and (2) Abraham is the subject of

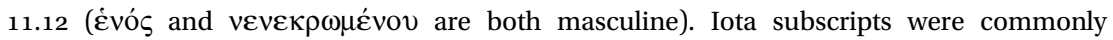
omitted in the dative in uncial manuscripts, and if this were the case here, then $\alpha \dot{\tau} \tau \dot{\eta}$ $\Sigma \alpha \dot{\alpha} \rho \rho \alpha$ may be read as a dative of accompaniment ( $\alpha$ vin̄ $\Sigma \alpha \dot{\alpha} \rho \rho \alpha$ ), rather than a nominative ( $\alpha \dot{v} \tau \eta \dot{~} \Sigma \dot{\alpha} \rho \rho \alpha$ ). By this reading, one could translate the beginning of 11.11 as: 'By faith also, along with Sarah, he received power to procreate' (see Attridge, Hebrews, 325-6;

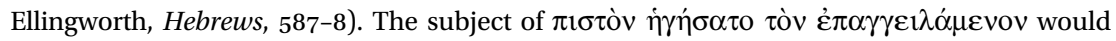
then be Abraham: 'he considered the one who promised faithful'. Nevertheless, a firm decision on this question does not impact our argument here. Whether it is Abraham or Sarah who expresses faith, in either case the faith being expressed is a faith in God in hope of resurrection.

50 Abraham is described in similar terms in Rom 4.19.

51 See also Moffitt, Atonement, 186.

52 For parallels to Heb 5.7-9, see Moffitt, Atonement, 192-3. 
element of faith being emphasized in both passages' ${ }^{53}$ Abraham, by willingly offering his son as a sacrifice, trusts God to fulfil his promise, even if Isaac died on the altar. ${ }^{54}$ Therefore, in both Heb 11.11-12 and 11.17-19 we see Abraham's trust in God connected with his hope of resurrection, either figuratively (11.1112) or literally (11.17-19).

\section{Conclusion}

Having looked at all cases where God is object of faith, we find that the motivation for this faith in each case is the hope that God will resurrect. This connection between faith in God and the hope of life after death provides a pastoral word to the hearers of Hebrews, who had faced persecution in the past. The author recalls their former days, when after 'being enlightened' they 'endured a great conflict of sufferings, partly by being made a public spectacle through reproaches and tribulations, and partly by becoming sharers with those so treated' (10.32-3). He praises them for previously 'showing sympathy to the prisoners and accepting joyfully the seizure of their property' (10.34). Furthermore, in encouraging the hearers to remember their former leaders and consider the outcome of their conduct, the author also probably alludes to leaders of the community who died for their faith. ${ }^{55}$

The author also expects them to face persecution in the future. Following the encomium on faith in the face of death in Heb 11 (as addressed above) and the depiction of Jesus' endurance of suffering in 12.2-3, in 12.4 he ominously says that the hearers have not yet resisted to the point of bloodshed in the struggle against sin. The 'sin' against which they struggle is probably a periphrasis for the 'sinners' from whom Jesus experienced hostility (12.3). ${ }^{56}$ 'Not yet' (oü $\pi \omega$ ) appears emphatically as the first word in the sentence. In view of the hearers' previous experience of persecution, the author in 12.4 is likely anticipating future bloody persecution for the community. This future persecution may be anticipated by imprisoned members of the community or those known by the community (like Timothy, 13.23), ${ }^{57}$ of whom the author encourages the hearers to 'remember those in prison, as though in prison with them, and those who are mistreated, since you yourselves also are in the body' (13.3).

53 Moffitt, Atonement, 192.

54 So also Moffitt, Atonement, 185.

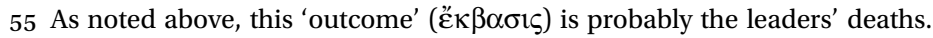

56 P. C. B. Andriessen, 'La communauté des 'Hébreux': Etait-elle tombée dans le relâchement?', NRTh 96 (1974) 1054-66, at 1062; H. Braun, An die Hebräer (HNT 14; Tübingen: Mohr Siebeck, 1984) 409; Lane, 'Living a Life of Faith', 250-1.

57 On Timothy's possible imprisonment, see Attridge, Hebrews, 409. 
The author of Hebrews exhorts this community who had been persecuted, is expected to be persecuted and may be persecuted currently (either in actuality or in their perception $)^{58}$ to be faithful. As I have argued at length elsewhere, faith in Hebrews is usually not a faith/trust/belief in an object, but rather an active faithfulness. ${ }^{59}$ Here we have investigated each case where faith has an object, and in each case that object is God. This faith in God, however, does not exclude the active faithfulness we see encouraged throughout Hebrews. Instead, faith in God (and in particular a faith in God's power to resurrect) gives motivation to faithfulness, expressed both in terms of bold endurance and patient hope. Boldness is possible because God promised the eschatological hope, and patience is necessary because God has not yet ushered in this hope. ${ }^{60}$ Jesus models this faith in God, as well as faithful endurance to the point of death (2.13; 5.7-9). With Jesus as their model and with their faith in the resurrecting God as their motivation, the author calls his hearers to be faithful in the face of their own deaths, and together to 'go to Jesus outside the camp, bearing his reproach, for here we do not have a lasting city, but we seek the city that is to come' (13.13-14).

58 On perceived persecution, see Lane, 'Living a Life of Faith', 248: 'And while they may not have been under actual persecution at the time, the perception of persecution can be just as shaking to a community as persecution itself'.

59 See especially Easter, Faith and the Faithfulness of Jesus in Hebrews, 181-214.

60 Koester, Hebrews, 310; G. Schunack, 'Exegetische Beobachtungen zum Verständnis des Glaubens im Hebräerbrief', Text und Geschichte: Facetten theologischen Arbeitens aus dem Freundes- und Schülerkreis. Dieter Lührmann zum 60 Geburstag (ed. Stefan Maser; Marburger Theologische Studien 50; Marburg: N. G. Elwert, 1999) 209-32, at 231; T. Söding, 'Zuversicht und Geduld im Schauen auf Jesus: Zum Glaubensbegriff des Hebräersbriefes', ZNW 82 (1991) 214-41, at 223-4. 